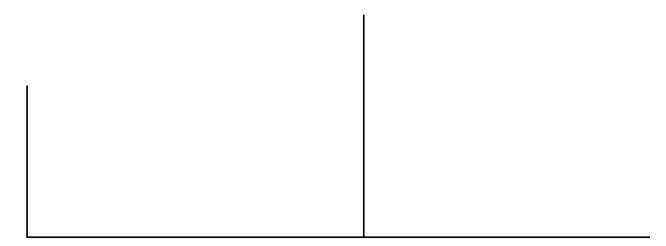

Rev. Latinoam. Psicopat. Fund., II, 4, 180-182

Metamorfoses entre o sexual e o social: uma leitura da teoria psicanalítica sobre a perversão

Carlos Augusto Peixoto Junior

Rio de Janeiro, Civilização Brasileira

1999

\title{
Metamorfose entre o sexual e o social
}

\author{
Maria Cristina Figueira Louro
}

Partindo de um percurso no qual a psicanálise se presentifica, o autor critica a tradição sexológica em suas perspectivas modernas e pós-modernas lançando luz ao estudo das perversões. Instigante pelo caráter interdisciplinar que apresenta ao recorrer à filosofia, às ciências sociais e, paralelamente, ao realizar contundente crítica a diversas teorizações psicanalíticas. Tenta desvendar as possíveis passagens do sexual ao social no tocante à perversão, pensando as complexas relações entre subjetividade, cultura e poder.

O objetivo fundamental evidenciado em toda a extensão deste livro é a demonstração do deslocamento teórico do domínio sexual para o social que, obviamente implicando a dessexualização da perversão, contribui para uma via menos moralizante e conceitualmente mais rigorosa e produtiva no tratamento dado pela teoria psicanalítica às perversões.

Segundo o autor, desde o início da década de 1980 a estrutura social assumiu um papel de extrema relevância nas tentativas de delimitação do problema da perversão em psicanálise. Frente a esta nova perspectiva, o arcabouço teórico psicanalítico presta-se, fundamentalmente, para 
detectar a montagem social perversa banhada em discriminações, manipulações e humilhações. Com efeito, é possível reconhecer aqui um certo abandono da dissecação da vida sexual privada em detrimento de uma análise minuciosa dos mecanismos de dominação perversa na esfera pública.

Durante todo o trajeto que o texto percorre é marcado o reconhecimento dessa perspectiva como sendo a contribuição mais verdadeira e profícua que a psicanálise e os analistas podem trazer para o enfoque da perversão. Nesse sentido, o autor acredita ser possível levantar aspectos das formações sociais que incidem sobre os sujeitos apagando diferenças e impedindo a plena manifestação de suas múltiplas subjetividades.

Em relação às críticas apontadas à noção de estrutura perversa, parece inquestionável a denúncia ao caráter regulador e normativo que a psicanálise exerceu em relação à sexualidade. Aproxima-se aqui da posição de Lantri-Laura que afirmara que a psicanálise teria unificado o tipo psicopatológico dos perversos em uma estrutura assentada nas proposições da renegação e da angústia de castração e que, portanto, tal tipo de discurso estaria apenas fornecendo à cultura as informações de que ela necessita para a regulação das condutas sexuais.

Vale ressaltar que na segunda parte do livro são enaltecidas as contribuições relacionadas às análises do fenômeno nazista por parte de Reich, Fromm e Marcuse. Apesar de terem sido de certa forma excluídos pela comunidade psicanalítica pelo estigma do revisionismo e culturalismo e, ainda que não tenham utilizado diretamente o termo perversão social, todos teriam colocado seu pensamento a serviço da elucidação de diferentes momentos histórico-sociais difíceis para a humanidade. Obviamente que cada qual recorrendo à utilizações pessoais do dispositivo psicanalítico criado por Freud.

Um ponto conceitual em comum entre Piera Aulagnier - apesar de ter sido uma das principais defensoras da estrutura perversa - e o autor refere-se à necessidade de um endereçamento aos laços sociais para uma melhor definição dos mecanismos psíquicos em ação na perversão. Em vez de ter ou ser o falo, o perverso seria apenas um objeto ambíguo que serve a um desejo que não o seu. Aulagnier mostra como a resposta perversa sempre traz consigo uma negação do outro enquanto sujeito; a identificação perversa se dá em função do objeto fonte de gozo para um falo não apenas fantasmático como também poderoso.

Na última parte são discutidos, fundamentalmente, os conceitos de laço e montagem social nas formações perversas que servem de instrumental teórico para a formulação de uma visão psicanalítica sobre as burocracias, as diferentes formas de totalitarismo, fascismo e racismo. Esses fenômenos são exaustivamente discutidos por serem reconhecidos como doença social pertinente ao nosso século.

$\mathrm{O}$ autor privilegia a noção de montagem social perversa brilhantemente evidenciada por Contardo Calligaris para elucidar questões sobre a burocracia. A 


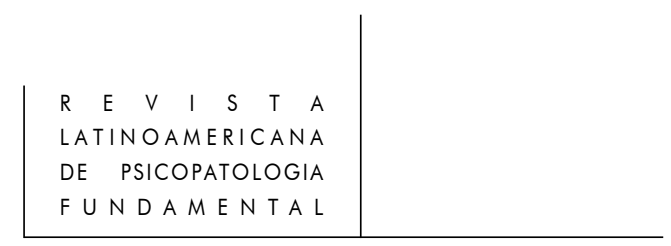

partir de uma abordagem eminentemente lacaniana, elabora a noção de laço social perverso e afirma que algumas posições neuróticas só conseguem se subjetivar dentro de montagens burocráticas. Indicado dois lugares do lado do sujeito na fantasia perversa - o do instrumento e o do saber - o perverso nunca está sozinho diante do Outro e situa seu gozo na usurpação do lugar do pai, acompanhada da apropriação do saber suposto a ele. Restaria portanto ao neurótico ocupar a posição de instrumento nas formações sociais perversas. Acaba por abrir mão de sua singularidade para perseguir o gozo do Outro, isto é, o gozo da montagem saber/ instrumento.

O essencial para o perverso é fazer com que este saber do qual ele se apropriou e que domina o gozo do Outro se apresente sem falhas, numa perfeita continuidade. A perversão, encontrando sua fenomenologia na vida cotidiana, ganha dimensão absolutamente diferenciada daquela dos desvios das normas da moral sexual.

Corroborando com a perspectiva de Jurandir Freire Costa sobre o homoerotismo, termo utilizado em substituição ao homossexualismo, não se trata de descrevê-lo como perversão sexual, mas considerá-lo como uma opção estética e, fundamentalmente, detectar a montagem social perversa de discriminação que está aí em jogo. Neste sentido reivindica-se critérios de análise eticamente mais satisfatórios.

Este livro indica as condições concretas de possibilidade do mal-estar que perpassam as relações humanas na modernidade. Reafirma, a partir de criteriosa pesquisa, que as relações sociais são permeadas pela perversidade. Busca desenfreada para demonstrar a dimensão perversa, em seu cerne constitutivo, tecida nas relações sociais. 